\title{
FREEDOM OF EXPRESSION AND MILITARY DICTATORSHIP IN PAKISTAN: CASE OF ZIA REGIME
}

\author{
* Dr. Shahnila Naz, Lecturer, Korangi Girls Degree College, Karachi - Pakistan \\ (Shahnila_1981@ hotamail.com)
}

\begin{abstract}
Martial law is considered to be a political disaster in any country and its survival then depends on the military government. Founder of Pakistan Quaid-e-Azam Muhammad Ali Jinnah also advised the military to remain loyal to the government and the constitution of the country. He never even thought about any constitutional role of the military which clearly indicates that Jinnah favoured democracy as the system of government for Pakistan. In this article, I focussed that military is a constitutional part of the government and can tell the president about the disorder in the country where the crisis is and what result there will be for the government. The military intervention of the army is subject to a few things, if these specific circumstances are not faced, then the military cannot intervene because their basic task is to protect the borders and to run the government is the task of the nation, I would like to highlight the violence of freedom of Expression and constraints for fiction writers during Zia ul Haq regime in Pakistan.
\end{abstract}

KEYWORDS: Government, Expression, General Zia, Politics, Pakistan.

\section{INTRODUCTION}

Political stability and border security are two separate tasks, and in the state of instability, the army gets involved in political and geographical borders. The army is concerned about whether there is no threat to the integrity of the country, and in that case the army is interested in politics. The army is asked to deal with the internal disaster and the worsening situation in the country and to counter natural disasters. (Siddiqui, 2002) Actually, any country's constitution is a sacred book for all its citizens, and the sacred book confirms all positions of high level in the country, and it confirms in a swearing ceremony. But if anyone make a conspiracy against this constitution, then he will be called a rebel and deserves its punishment. The above-mentioned respect is not part of any country' constitution, but it is available everywhere in the world. Constitution in decent communities is recognized as a sacred book, and we all are 


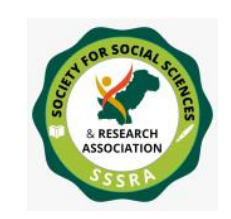

Pak. Journal of Int'L Affairs, Vol 1, Issue 2 (2018)

Freedom of Expression and , ...

considered to be the most sacred religion of this world, which gives the highest degree of love, brotherhood and compassion. But unfortunately, some of the high ranked generals of the Pakistani forces have taken the oath and after taking their oaths, they have damped its magnitude and its an example within itself. Many times, in Pakistan, constitution was suspended and even dismissed. (Choudhri, 1989) Regarding martial law, once asked from Maulana Maudodi, he said that this government is a bad thing in itself and it is only better to get rid of it as we get the opportunity because the elite class has to right to rule the people. (Tariq, 1976)

\section{NEWSPAPERS, MAGAZINES AND CENSORHIP POLICY OF ZIA UL HAQ}

General Zia's martial law created a constitutional crisis in the country and the constitution which was the result of civic struggle and efforts, General Zia disable to it and paralyzed the political rights and freedom of the people. Various means were used to bring emotions in the public against democratic institutions and politicians. By using the name of Islam, he promised the election, but all the promises were not only violated, but also on the other hand, the democratic provincial movements were supressed with the use of power. These government initiatives mislead the state's international impression and thus the state joined the list of backward states of the world where the public opinion and their basic rights were banned. (Mehmood, 1989)

A non-political attitude in the rule of martial law is that they join hands with different provincial and religious groups and organizations by themselves to strengthen their position and their governments and they work for government's interests. These groups put pressure on newspapers and magazines in its favour to get benefits.

This was described by Hasan Abidi in an interview (Abidi 2005):

"During the Zia-ul-Haq's period, direct pressure from political groups was increased on newspapers. For example, when an organization had captured the city and it also got official patronage, the newspaper received telephone calls that we're sending a news and this news should be included in the seventh or eighth column on the front page. Such threats were also given that the news should be published or else 


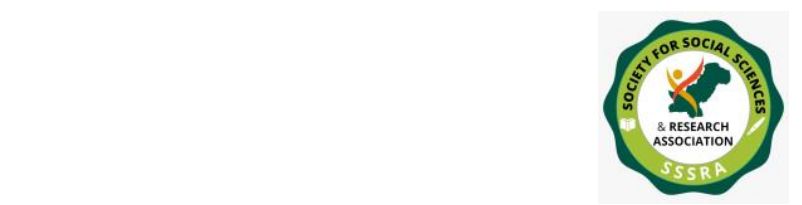

Pak. Journal of Int'L Affairs, Vol 1, Issue 2 (2018)

Freedom of Expression and ,...

we'd see you tomorrow, we know where your daughter

is studying at which school or by which route your child goes to school. Bomb blasts were carried out on their office, terror was spread in the country and it was felt and anything could be done by force. I believe that the newspapers compete with the steadfastness of the governments, but when the linguistic and religious groups they started to attack on newspapers, they were not condemned by the journalists."

During the period of General Zia, newspapers had to go under the censorship policy and thus the people did not get the right facts. The therapeutic treatment was done by the media community that they would either leave the censored section blank or they would be inked on those words so that the public could know that newspapers want to inform them with the truth, but the government workers did not give them the opportunity. Most of the newspapers were under the censorship policy in martial law at that time. Daily newspaper "Masawaat" was discontinued. This work had created anxiety in the government because it was held responsible for this censorship and now they wanted this act of inking or leaving blank spaces to stop. (Tahir, 1987)

The sister of Pakistan's founder Fatima Jinnah also expressed her views on how much freedom should the newspapers have and what their role in the society is, she said that it plays an important role in the way of independence. Their freedom should not be slated because freedom of newspapers stabilizes the spirit of democracy. If the newspapers do not inform the public about foreign affairs and international affairs without pressure or transparency, then the delicate plant of democracy will never be able to flourish in the country. (Anjum, 1993) Because democracy is considered a symbol of unity, equality, friendship, tolerance and mental harmony. Its spread is a revolution in the world of literature. Despite of encouraging society's civilization and culture, they are also protected. History witnesses that writers have played their historical role around exploitation forces around the globe, but the writers of the backward countries are tied in many ways, they are targeted by both government and society. (Ahmed, 2002) At the time of General Zia, a literary episode, "Adib al-Latif" was also targeted. After Nasir Zaidi, Siddiqa Begum was very brave with her friend Kishwar Naheed, Ghalib Ahmed and Zulfikar Tabish to publish this magazine. From 1981 to October 1985, this article continued to make protests despite the government's hardships and the 


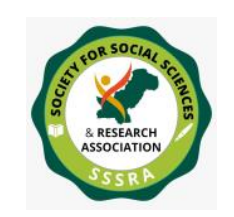

Pak. Journal of Int'L Affairs, Vol 1, Issue 2 (2018)

Freedom of Expression and ,...

political oppression continued to resist the fear of the non-functional movement. Kishwar Nahid says that after changing the name of the writers and after passing through the censorship, the time of printing were corrected and the incident indicates how the victims were censored and censored in the case of General Zia. (Hussain 2004)

When we look at the history of Pakistan of 10 years of martial law, everyone is seen in fear, insecurity and freedom of speech. Again, in the 1977 , the country was once again hit by martial law, prime minister was hanged and protesters were put in the prisons. In this era, the poets and authors could not remain silent and created a literature that could not be found in the past. ((Hussain 2004) One of the things that the authors and artists were not silent in the era of General Zia appeared that the affidavit of communication was not available at the national level. (Ahmed, 2002) Democracy is respectful of self-determination and discrimination despite the flaws but martial law is contrary to democracy and it is the name of working in force, and democratic values are not accepted in this system. Democracy is also a political and social system as well as a viable feeling that makes the society open minded and it is also inevitable for the development of literature. The development of literature is subject to the development of democracy, it is so strong and stable it is in itself, that even the oppressor of the greatest is not denied it. In fact, they themselves took the support of literature and deceived the people. (Shamim, 2002)

The work of the nation's intellectual leadership is not of government, but the work is of the authors of this country. Along with this, they mentioned two intellectual behaviour, saying that one thought is related to the ideology of Islam and the other thought is related to secularism. General Zia was very opposed to secular groups because according to them Pakistan was an Islamic state and there was no secular group in such a state. Regarding his martial law government, General Zia expressed the views that no other restriction has been made during the period of his government because the person who believes in Islam accepts all restrictions. The people who do not like these restrictions can leave the country, according to the general Zia, his government has neither banned the pen or has stopped anyone's thinking. General Zia expressed concern about why there is so much difference in thinking of people who believe in one Allah, one messenger and one book.

Along with the authors, General Zia also gave a part of the discussion of the journalists, asking them why they only present insecurity 


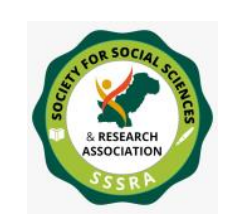

Pak. Journal of Int'L Affairs, Vol 1, Issue 2 (2018)

Freedom of Expression and , ...

and terrorism instead of seeing the country's social and economic prosperity. A group of writers, poets and journalists had made a protest against the government, and if all these matters mean anger and dissatisfaction with the government, they are allowed because the martial law government did not ban freedom of expression, but such people should go out of Pakistan and should also study the situation, then they will learn their lesson on freedom of expression. The poets, writers and journalists who are the real representatives of any country's values and thoughts, didn't get the advice of General Zia ul Haq when photographs of his oppression emerged in front of them.

When General Zia enforced his martial law, at that time an agreement was reached and there was a compromise between the government and the opposition, and the differences between the two were over. This agreement was lacking a signature but before that General Zia announced third martial law in the country and reason for this martial law was given that the country's situation is declining due to the differences between the opposition and the state's disasters continue to worsen. But within 90 days the elections were promised in order to give the authority back to the people. General Zia's martial law was recognized stronger than the previous two martial laws of the country as any opposition to it was badly oppressed. The zakat was collected in name the Islamic system by the martial law government, but it was used for which people, did not have any evidence - it would also be a political interest. (Choudhri, 1989: 135136)

The martial law was also in danger of various convictions such as freedom of expression and corruption, as well as domestic peace. Where the job-makers feared coming out of the house, did not know whether they would return or not, and that they were not safe in both cases whether inside or outside of their homes. General Zia decided to punish according to the Quran and Sunnah, and included alcohol, adultery, false accusation and robbery in the crime in order to purge the society from such heinous crimes. According to General Zia, implementing such limits in society would reduce problems and create a crime-free society.

When General Zia removed his elected prime minister, his action was not appreciated and the politicians protested against him. While addressing a function, former federal finance minister Dr Mubashir Hassan mentioned general Zia's intentions and also pointed out that a president with extraordinary authorities can be dangerous for the nation and national 


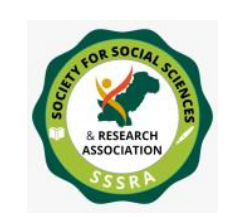

Pak. Journal of Int'L Affairs, Vol 1, Issue 2 (2018)

Freedom of Expression and , ...

security. General Ayub and General Zia in Pakistan are examples of this and people should get lessons because their decisions have damaged the country. General Zia was not bound to his words, because he promised to organise elections on a party based system, but he gave an announcement for non-party based elections through a press conference, which spread anxiety in political constituencies. This was considered as a violation of the constitution.

On the other hand, during General Zia's era, the entire society was on the rise of bribery and corruption. General Zia also acknowledged that. The military officers were also involved in bribery and trafficking, but no action was taken against them, resulting in the fact that the army's professional suffered serious illness of corruption. Near 1978 and 1985, Zia found a way to finish Pakistan's change into a religious government of the medieval assortment. A Federal Shariat Court was made for upholding religious laws, striking down laws it discovered offensive to Islam, and with some energy to make laws. The state expected the ability to gather zakat and ushr. Ahmadis were banished from calling their supplication houses mosques, from having and perusing the Quran or utilizing the Muslim methods for welcome each other, utilizing Islamic appellations or naming their little girls after ladies having a place with the Holy Prophet's (PBUH) family.

The Penal Code was revised to accommodate discipline for despoiling of the Holy Quran and for rebuffing sacrilege with death or life detainment (later on the Shariat Court made passing for lewdness obligatory). The parliament was assigned as the Majlis-e-Shura, and a subjectively altered Objectives Resolution - utilized until now as a preface to the constitution - was made its substantive part. Moreover, an endeavour was made to subvert the arrangement of vote based races by holding party-less surveys.

Moreover, Zia corrected the established arrangements identifying with capabilities for enrolment of congregations and exclusion of individuals to make them suggestive of regard for religious criteria. $\mathrm{He}$ likewise subverted the training framework, initially by encouraging the development of religious theological colleges (while augmentation and change of general instruction were disregarded and books on rights and popular government were singed) and expanded religion-related lessons in reading material at all review levels. Encourage he endeavoured to combine his measures through an established change (the ninth alteration) 


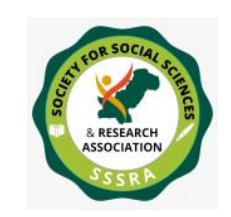

Pak. Journal of Int'L Affairs, Vol 1, Issue 2 (2018)

Freedom of Expression and , ...

yet it was not received. He was likewise unfit in his endeavours to make ethical quality units to uphold the arrangement of supplications and rigid controls. Just like Ayub Khan established Council of Islamic Ideological, Zia ul Haq also established Shariat Courts. But the strange thing was that the decisions of these courts were often not accepted by the government. Political aspects were hidden behind the general Zia's implementation of the Islamic system because according to General Zia, western-style democracy is incredible and non-Islamic for Pakistan. This democracy is hazardous for the country because of not being compatible with the awareness of Muslims and that Islam does not support any sort of election campaign and electoral process. How much Zia loved the country and how much he respected the nation in his heart, could be described in a statement, when he said that he is accountable in front of God, but later opposing their own words he stated that he is accountable in front of God, conscience and the nation. (Choudhri, 1989: 134-136)

Regarding politics in his address, General Zia said that he would never oppose politics, if the government was under the name of politics, then the government would oppose him and Islam would not allow such politics in which the politicians keep the power occupied. He criticized the past system and described him as a robbery that was not fit on our bodies. He criticized the past system and described it as a robbery that was not fit on our bodies. Unlike this system, General Zia's government wanted to enhance the implementation of Islamic democracy and assured that elections in the country would definitely be held but on the other hand, he refused to accept the right to represent his territory. While saying, Islam does not accept such actions, but gives the right to represent people with passion and service. Referring to some constituencies regarding election, General Zia said that some people are afraid of elections and dislike it, they ask me to not hold elections, but I am confident in organising elections in the country.

\section{THE IMPORTANCE OF SYMBOLIC EXPORESSION IN RESTRICTED SOCIETY}

If we consider the Symbolism movement, it comes to the fact that the symbols emerged as a reaction to scientific realism and thus called a regular movement. The poets originally presented the concept of a perfect world in opposition to consciousness. The movement started with the movement of Budaleer, who saw nature in a symbol of reality. His writings also influenced by other poets, and in this regard his poem called 


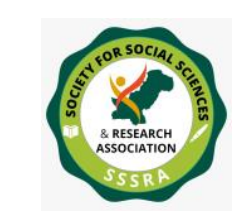

Pak. Journal of Int'L Affairs, Vol 1, Issue 2 (2018)

Freedom of Expression and ,...

"Evil Flowers (Badi ke Phool)" is also called producer of movements. The translations of writing from Edger Allan which were done by Budaleer, have a prominent role in symbolism movement. Edgar Allen profited the symbolic movement with his criticism. Prominent names from this $19^{\text {th }}$ century revolution were Warlen Malarmay and Rambo. The poets used to go out of the words of routine and used to talk about just feelings and aesthetics and their associated situations. Music in this movement plays a high position, and the poets consider music as a type of poetry. (Hasni, 1996)

The movement, along with poetry, is also makes a step in the novel world. Marshall Prost was the first to be inspired by this movement and his novel "Research of Ancient Period (Tehqiq-e-Zamana-e-Qadeem)" was considered to be the best literature of symbolic philosophy. The way this movement affected England, Germany, and other countries, similarly the intellectuals of Urdu could not have been affected as well and the representative of this movement was Mira Jee. Along with Mira Jee, there was the poetry of NM Rashid, Faiz Ahmed Faiz, Akhtar ul Imaan, Qayum Nazar, Yousuf Zafar, Mukhtar Siddiqui and Zia Jalandhari included. (Hussain 2004)

When we look at the past of the Pakistani nation, one thing is seen very intensely that the people of this nation never get a peaceful life but become helpless due to compel political situations and events and that it is a nation whose status is not recognized. It was almost everybody who came to power by pleasing his lord America. At the time, the people of society were also quiet under fear. (Hasni, 1996)

In previous pages, it has been clarified that Pakistan had been a victim of martial law and the dream to achieve democracy in the country was difficult due to perpetual martial law in different times. No serious steps were taken for democracy in Pakistan. Consequently, the society did not face democracy with democratic behaviour, and thus the nondemocratic attitude took birth. In Pakistan there was an extreme lack of delights like democratic behaviour, freedom, tolerance, importance of disagreement and patience. Our society could not get rid of the feudal system, due to which neither the industrial system was developed, nor the plant of democracy flourished. Pakistan got its first constitution nine years later, and then what did happen to this nation is in front of the world. Because democracy is considered to be the cause of prosperity of the society, its essential influence is also on literature. Literature of a 


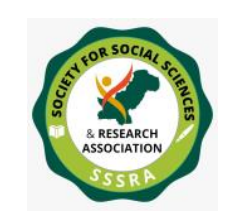

Pak. Journal of Int'L Affairs, Vol 1, Issue 2 (2018)

Freedom of Expression and , ...

democratic free society is also democratic and the prosperity of literature is based on the growth of democracy. The military government banned the publication of newspapers and magazines, people were deprived from the truth and in such a way the world of poetry and literature started to use gestures and symbolic language. Now, the poets and the authors were forced to cover the matter. (Ahmed, 2002)

At the time of General Zia, the authors were facing a lot of difficulties. The instrument that was used to check their writings was sad and the reaction also appeared. Instead of examining the talents and art of literary skills, art was subject to political commitment. There was another cruel thing that if the author is not affiliated to the right or left wing then he would be forced to affiliated to any of the wings. Such kind of behaviour with the writers came from the literature and journalism, the literary test was taken on political grounds rather than literary ones. (Monthly Awaraq, 1981)

The fact that is accepted by all is that General Zia's dictatorship was the country's longest and most horrific period. The writers, poets, politicians were all affected. Generally, all these people were lashed during the time of General Zia's martial law. If we say that martial law affects our literary world as well as affecting the events and politics of Pakistan, it will not be wrong. (Manzar, 1997) The writers and the poets began to fear the expression of their views openly and started a period of symbolic writings in society. The result was that the people got rid of the literature and did not fully understand the literature as well. When people did not understand the literature, the hard work of authors and writers went useless. The beauty of the symbol is hidden in its layers. In the creation of good symbols, the writer will take care that the symbol is derived from his community. Symbols that are derived from other societies cannot completely affect the reader's mind. Because every society has its own specific environment and beliefs that are not completely compatible with other societies. That is why it is better to find the symbol in your society's life. There is also a tradition of the creation of a symbol. Every society consists of a variety of academic and literary traditions that are part of the lives of its people. If the writer presents these narrative skills to them, then the symbol comes from the tradition of refreshment with the tradition of their writing. Here we lack the use of symbols in traditions, due to which the reader is away from literature due to untouchable Western life or Greek and fictional symbols. Symbols collected from the contrary Islamic traditions do not have problems with communication. The birth of a 


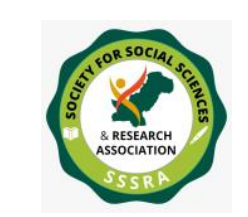

Pak. Journal of Int'L Affairs, Vol 1, Issue 2 (2018)

Freedom of Expression and ,...

gestural way in the creation of a symbol can also create a beauty, and the success of this book is also considered to be present in the literary world of the society and any other design that is valuable as well as understanding. Even the beauty of private sign is implicit in the fact that accessible to the reader's mind is another sign for the sign that it is important to keep the sign in mind to recognize it, otherwise they are not recognized. (Aqeel, 2005)

Actually, in the Pakistani society, before the behaviour of symbolism, the tradition of social reality was the tradition, and the work of breaking our tradition was done by our new generation. Because of fact, all the elements and perfections were visible in the twenty to twenty-twoyear period and now the authors were repeating themselves. There will be a search for a new atmosphere in such a way that the attitude of military governments and its hardships in the country, in which our young poets and writers pushed them into the world of symbols. (Jalbi, 1984)

The history of resistance is subject to a history of history and both of them are similar to each other. Resistant literature can be as much as possible or because there are conflicts in the society. One trend about this literature is that it is not literally literary, but it is an emergency or timely literature. Although authors create literature from the events around him, as a human being, he creates literature, does not run but face it because he is responsible. Fictions related to resistance and protests, such as "Gawahi" have great importance, through which the authors have hidden in the curtains of the symbol and have conveyed their voices to the masses. (Ahmed, 2002)

\section{SYMBOLIC EXPRESSION: CONFLICTS AND CONFIRMATION}

Exiting the discussion in previous pages, we simply consider the question whether effective way of expression is symbolic or non-symbolic. In this case, we have the opportunity to talk about different conversations in which some like this method and some are awake. Dr. Jamil Jalbi says that a symbol of innovation has emerged as a ghost in this new trend. Because this class has transmitted a new generation of poets on a monkey road and they do not have to get out. A time in which the process of repeating the fate of the writers prevail, rather than the new paths, it is going to reinforce the journey that is fixed. The course of which resulted in the distress of beauty of their writings. One of the major arguments behind this is that many big and important fictionists also find that the fiction of 


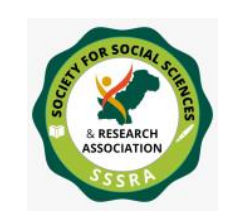

Pak. Journal of Int'L Affairs, Vol 1, Issue 2 (2018)

Freedom of Expression and ,...

modern era is in danger of communication issues and it is not a common person, but with strong grip on self-literacy paths of the goats, the important thing in this case is that the symbolic philosophy is not a cup of tea for everybody, now the art evolution has stopped and new generation talents are exploiting their abilities. There is no awareness of the problem, nor does he have any issues. It's a matter of shame. He does not even understand why he is writing and for whom - the issues of communication are on rise. Experiencing these experts will spread only anarchy, there is no benefit on the degree and creative level, because the sign does not expose the fact that symbols are presented through reality and our legendary symbols are facing the same difficulty, because they are unaware of the art of reality, they cannot even create a good sign. (Jalbi, 1984)

The symbol is related to the art of an artist, it is out of itself all its beauty, and it is a good idea to give the truth a new meaning. It also brings the narrative tradition to it, that is why some symbols are permanent, which is not possible for fury. Usually it is said that the martial law tale pushes the opponents to symbolism, it is doubtful because if Pakistan literature is competed with Indian literature, where Pakistan remains victim of martial law, meanwhile democracy in India was bright with its entire climate but the symbolic behaviour in literature continued to be similar as that of Pakistan. So, this is not true, but in the path of modernity, some new ideas can be called symbolic fiction. The other important thing is that the movement was very important but the importance of the person was nothing near it. The people of the earth did not even understand the sky. So spiritual values are more than this movement. Again, before independence, the conditions of imperialism were something else, while life was changed after independence. Now there was no peace in the sky, but the sky above the person and the earth appeared to the sky. Thus, man's internal accessibility process started. (Saded, 1984)

In relation to the birth of symbols, Agha said that it is a global event that is not the reaction of a radical movement or the creation of Martial Law, but in the 19th Century that was the century of science's selfesteem, it was tremendous because science It was frustrated that he has completed the discovery of the universe, but when the curious curtains on the universe began to grow more and the atom was discovered, the human mind felt a shock and felt that some more secrets of reality still existed. The rest, in such a way turns towards the social symbol and the discovery of the truth begins. Minister Aga Sahab signifies the negligence as a 


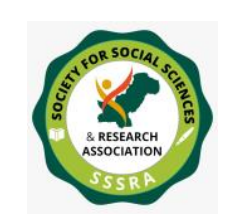

Pak. Journal of Int'L Affairs, Vol 1, Issue 2 (2018)

Freedom of Expression and ,...

positive movement and according to them, the symbolic legend will also be positive. Along with this, he is not even embarrassed for the promotion and dedication of symbolic fiction, according to him, in modern logical fiction, it is more difficult to imitate delicate and delicate situations. While Romance and Realists do not suffer from this problem. They think it is necessary to have a limit between abstract and symbolic fiction and they believe it is two separate things.

The creation process is not a matter of transaction, some responsibility of communication is also applied to readers and secondly when the author is aware of the creation, it will be known to the reader, but if creation is unaware, then the consciousness of communication is also incredible. A real creation is the one who reaches the heart and mind of his reader.

\section{CONCLUSION}

To close, from Jinnah to Zia, governmental issues in Pakistan rotated around identities. Educated by a self-serving and particular perusing of Muslim history, frontier inheritance, and social conditions, an enduring mission in Pakistan for 'phenomenal men' generally ruled out the lesser initiative after the death of Jinnah and death of Liaquat Ali Khan. Lesser government officials neglected to convey. They could neither move wonderment among the general population nor stop political manoeuvrings by the more created administration and military. Factors, for example, absence of education, joblessness, destitution, scattered gathering governmental issues, and political agitation encouraged praetorian interruptions. Government officials recuperated some ground after the military annihilation in 1971 yet neglected to use the respite to reinforce gatherings and majority rules system. The arrival of praetorians couldn't be averted for all circumstances essentially by expository metaphor or under the risk of reformatory protected statements. A maintained political culture of resistance and convenience was as important just like the political strengthening of the general population, improvement of the media, the political gatherings, and the legal. Indeed, even Bhutto, apparently the nation's most prominent pioneer after Jinnah, couldn't put Pakistan on the way of majority rule government, as he refused contradict inside the PPP, checked the resistance and the press, and looked to control legal. The partisans of Bhutto ought to have learnt the significance of sorted out legislative issues and systematized control after the fall of his legislature and his miserable completion. The military, 


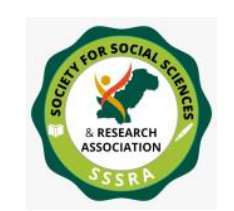

Pak. Journal of Int'L Affairs, Vol 1, Issue 2 (2018)

Freedom of Expression and ,...

regardless of how taught or all around prepared, would never ride roughshod in Pakistani legislative issues, if it somehow managed to confront the apparition of composed restriction. In spite of being a famous lawmaker, Bhutto was not able, similar to his antecedents, to make an interpretation of individual ubiquity into well-known help for institutions. By his own confirmation, he had no time for party association. The burden of Zia's Martial Law must be seen, subsequently, as the result of that waiting break of institutional advancement in Pakistan which gave its better sorted out armed force an edge over the rest of the substructures of the State and political powers. Its brutalities were in reality corresponding to its own weaknesses, the radicalization of national governmental issues and the flexibility of the PPP. Zia administration depended vigorously on pressure, moderate elites, religio-political associations, and its remote companions. Affability of the military administration, religious initiative acknowledged secondary passage section into control and tasted fleeting expert past its discretionary potential. To legitimize itself and to secure business as usual, it transported religion into legislative issues and built up a nexus with the standard ulema whose learning and understanding of Islam and general perspective was medieval and disharmonious to the perspectives of Iqbal and Jinnah who saw present day popular government and the parliament in culminate concordance with Islamic lessons, and were against tyranny, whatever its frame. Eleven years of Zia were the squandered a very long time the extent that vote based system is concerned. Indeed, even his demise did not expel obstructions to majority rule government. Four chose governments fell rashly and in succession because of the counter law based protected advancements of Zia, i.e., the Eighth Amendment, which changed the nation's parliamentary framework into a presidential one aside from in name. As chose governments would hold office amid the joy of the in a roundabout way chose president, it made joke of equitable standards. 


\section{REFERENCES}

Siddiqui, H. R. (2002) Pakistani Siyasat: Fouj, Beurocracy, aor siyasi jamato ka kirdar 1947 - 1958, Bacan Baks Multan, pp-57-59

Choudhri, M. A. (1989) Marshall ka Siyasi Andaz, Jang Publishers Lahore, p-52

Tariq, M.A. (1976) Amriyat ki Kharabian, Islamic Publications Limited, Lahore, p-233

Mehmood, S.,(1989) Pakistan ki Tareeq wa Siyasat 1947-1988, Jang Publications, pp-94-95

Abidi H, (2005) Jino me Jitni bhe Guzri, Pakistan Study Center, university of Karachi, Karachi p-115

Tahir, S., (1987) Marshall-Law ka White Paper, Classic, Lahore, pp-185186

Anjum, W., (1993) Shama millat Fatima Jinnah ki taqrirain, Jang Publishers, p-163

Ahmed, A., (2002) Mazahmati Pakistani Adab, Zahen Jaded, New Delhi, p-80

Hussain S., Dr., (2004) Mutala tehqiqi aor tanqidi mazameed ka jaeyza, Bahauddin Zakria University Multan, pp-92-93

Shamim, M., (2002) Awarish, Jawadan Publishers, pp-73-79

Hasni, M., (1996) Tehrikat Urdu Adab, Fahad Publishers, Lahore, p-342 Monthly Awaraq (1981) Lahore, pp-13-14

Manzar, S., (1997) Pakistan me Urdu Afsano ke Pachas Sal, Pakistan Study Center, University of Karachi, pp-163-164

Aqeel, S.,M., Dr.,(2005) Malamat Nigari ki Tehreek, Bait ul Hikmat, Lahore, p-16 
Pak. Journal of Int'L Affairs, Vol 1, Issue 2 (2018)

Freedom of Expression and ,...

Jalbi, J. Dr., (1984) Sawal Ye Hy, Alamati Afsana Aik Manfi Rujhan, Monthly Aowaraq,, March, p-10

Saded, A. ., (1984) Sawal Ye Hy, Alamati Afsana Aik Manfi Rujhan, Monthly Aowaraq, March, p-18 